\title{
Iron biofortification in rice: in search of morphological traits for indirect selection in breeding programs
}

\author{
Biofortificação com ferro em arroz: em busca de caracteres morfológicos para \\ seleção indireta em programas de melhoramento
}

\begin{abstract}
Cássia Fernanda STAFEN'; Ana Marina PEDROLO²; Fernanda Pollo PANIZ³; Tatiana PEDRON4; Carlos BUSANELLO ${ }^{5}$; Eduardo VENSKE ${ }^{6}$; Ariano Martins de MAGALHÃES JÚNIOR ${ }^{7}$; Bruno Lemos BATISTA ${ }^{8}$; Antonio Costa de OLIVEIRA $^{9}$; Camila PEGORARO ${ }^{10}$
\end{abstract}

${ }^{1}$ Bióloga, Mestre em Agronomia. Centro de Genômica e Fitomelhoramento, Departamento de Fitotecnia, Faculdade de
Agronomia Eliseu Maciel, Universidade Federal de Pelotas. E-mail: cassiastafen@outlook.com
${ }^{2}$ Engenheira Agrônoma, Mestre em Agronomia. Centro de Genômica e Fitomelhoramento, Departamento de Fitotecnia,
Faculdade de Agronomia Eliseu Maciel, Universidade Federal de Pelotas. E-mail: anapedrolo@gmail.com
${ }^{3}$ Bacharel em Química, Mestre em Química. Centro de Ciências Naturais e Humanas, Universidade Federal do ABC. E-mail:
fernanda.p@ufabc.edu.br
${ }^{4}$ Bacharel em Química, Mestre em Ciência e Tecnologia / Química. Centro de Ciências Naturais e Humanas, Universidade
Federal do ABC. E-mail: t.pedron@ufabc.edu.br
${ }^{5}$ Engenheiro Agrônomo, Doutor em Agronomia. Centro de Genômica e Fitomelhoramento, Departamento de Fitotecnia,
Faculdade de Agronomia Eliseu Maciel, Universidade Federal de Pelotas. E-mail: carlosbuzza@gmail.com
${ }^{6}$ Autor para correspondência: Engenheiro Agrônomo, Doutor em Agronomia. Centro de Genômica e Fitomelhoramento,
Departamento de Fitotecnia, Faculdade de Agronomia Eliseu Maciel, Universidade Federal de Pelotas. Campus Universitário
do Capão do Leão, Avenida Eliseu Maciel sem número, CEP 96010-610. E-mail: eduardo.venske@yahoo.com.br
${ }^{7}$ Engenheiro Agrônomo, Doutor em Agronomia. Empresa Brasileira de Pesquisa Agropecuária - Embrapa Clima Temperado.
E-mail: ariano.martins@embrapa.br
${ }^{8}$ Bacharel em Farmácia, Doutor em Toxicologia. Professor Adjunto, Centro de Ciências Naturais e Humanas, Universidade
Federal do ABC. E-mail: bruno.lemos@ufabc.edu.br
${ }^{9}$ Engenheiro Agrônomo, Ph.D. em Genética. Professor Titular, Centro de Genômica e Fitomelhoramento, Departamento de
Fitotecnia, Faculdade de Agronomia Eliseu Maciel, Universidade Federal de Pelotas. E-mail: acostol@terra.com.br
${ }^{10}$ Engenheira Agrônoma, Doutora em Agronomia. Professora Adjunta, Centro de Genômica e Fitomelhoramento,
Departamento de Fitotecnia, Faculdade de Agronomia Eliseu Maciel, Universidade Federal de Pelotas. E-mail:
pegorarocamilanp@gmail.com

Recebido em: 17-12-2018; Aceito em: 06-03-2019

\begin{abstract}
Iron (Fe) deficiency is an important cause of health concern in developing countries, demanding mitigation strategies to fight this disorder. The biofortification of staple foods, such as rice (Oryza sativa L.), could be achieved via the development of improved cultivars. Iron quantification is relatively costly and time-consuming, making its routine use impracticable in breeding programs. Therefore, the identification of traits to be used in indirect selection strategies would be of high interest. This study aimed to find promising traits for use in indirect selection programs aiming Fe biofortification in rice grains. A diverse set of 95 rice genotypes, mostly Brazilian, was grown at Southern Brazil, in 2016/2017, and Fe content in brown and polished grains, as well as other 12 morphological traits, were assayed. Analysis of variance, linear correlation, and path analysis were carried out. Different levels of association between traits were found, being panicles per plant and caryopsis width the most promising for use in indirect selection aiming increased Fe content in both brown and polished rice. However, secondary traits, such as caryopsis length, have also to be considered when performing selection aiming Fe biofortification in the cereal.
\end{abstract}

Additional keywords: breeding strategies; correlation; mineral content; nutritional quality.

\section{Resumo}

A deficiência de ferro (Fe) é uma importante causa de preocupação em termos de saúde em países em desenvolvimento, demandando estratégias de mitigação desta desordem. A biofortificação de alimentos-base da dieta, como o arroz (Oryza sativa L.), pode ser alcançada através do melhoramento genético de cultivares. A quantificação do teor de ferro é relativamente cara e demorada, fazendo seu uso rotineiro impraticável em programas de melhoramento. Assim, a identificação de caracteres para serem utilizados em estratégias de seleção indireta é de elevado interesse. Este estudo objetivou encontrar caracteres promissores para seleção indireta, objetivando biofortificação de ferro em grãos de arroz. Um painel diverso com 95 genótipos de arroz, a maioria brasileiros, foi cultivado no Sul do Brasil, em 2016/2017, e foi avaliado o conteúdo de Fe em grão integral e polido, assim como 
outros 12 caracteres morfológicos. Foram realizadas análise de variância, correlação linear de Pearson e análise de trilha. Diferentes níveis de associação entre os caracteres foram observados, sendo panículas por planta e largura da cariopse os mais promissores para uso em seleção indireta objetivando incremento no teor de $\mathrm{Fe}$, tanto em arroz integral como polido. Entretanto, caracteres secundários, como comprimento da cariopse, também devem ser considerados ao realizar a seleção, visando à biofortificação com Fe nos grãos do cereal.

Palavras-chave adicionais: estratégias de melhoramento; conteúdo de minerais; correlação; qualidade nutricional.

\section{Introduction}

Rice (Oryza sativa L.) is one of the most important staple foods for humankind, comprising the largest part of the diet of more than half of human population (Mohan et al., 2017). In rice breeding programs, the development of cultivars with improved yield potential has been the primary target. However, quality and nutritional aspects of the grain have risen in relevance, for many reasons (Sharma et al., 2017).

Nutritional quality of food, particularly mineral content has become more important over the years (Saltzman et al., 2013). Among nutrients with high importance in the human diet, iron $(\mathrm{Fe})$ receives high attention, as it is crucial to many biological functions (Khush et al., 2012; Murgia et al., 2012; Camaschella, 2015; Vasconcelos et al., 2017). The deficiency of this element is one of the most critical health problems in developing countries, most places where, at the same time, rice is the staple food (Stein, 2010; Hackl et al., 2017). Biofortification with $\mathrm{Fe}$ in rice grains, through breeding improved cultivars, is the most convenient and impacting mitigation strategy against the deficiency of this micronutrient (Bouis \& Welch, 2010; Sperotto et al., 2012).

There is important genetic variability for $\mathrm{Fe}$ content in rice grains (Zhang et al., 2004; Anandan et al., 2011). However, it is a complex quantitative trait, showing intermediate heritability, thus profoundly affected by the environment (Huang et al., 2015). It is also a trait of difficult evaluation, i.e., relatively costly and time-consuming, requiring specific analytical analysis to determine the content in food. Additionally, it involves the use of mature grain for analysis, thus direct selection at early development stages of the plant is not possible. In this regard, indirect selection is a convenient alternative (Carvalho et al., 2004).

Indirect selection is based on one or more secondary traits aiming to select and thus improve another trait, the main object of selection, exploring the association among traits (Falconer, 1981). For a successful indirect selection, the secondary traits must be easier or cheaper to evaluate in comparison to the main trait. Furthermore, more convenient is the selection, when the secondary traits are also of agronomic interest, so the crop can be improved for many traits simultaneously. Phenotypic, genotypic or environmental correlations can exist between traits, being the genotypic correlation the most informative for breeders, as it captures trait heritabilities. Genotypic correlations are explained mainly by pleiotropy or gene linkage genetic phenomena (Falconer \& Mackay, 1996; Nogueira et al., 2012).

Despite the enormous potential that indirect selection offers, some aspects deserve attention. In many cases, the correlation among traits has not a "cause and effect" nature, not allowing a direct interpretation of a linear correlation. In this regard, a strong association between two traits can happen due to the indirect effect of a third trait or even more traits. Thus, special analysis, such as the Path analysis (Wright, 1923) allow a better understanding of the real association between the traits under analysis and thus a better application of the results (Wright, 1921, 1923; Nogueira et al., 2012; Barbosa et al., 2017).

Therefore, the present study aimed to investigate the association between morphological traits, including of agronomic importance, and Fe content in rice grains, verifying the most promising ones for use in indirect selection in breeding programs aiming iron biofortification in rice.

\section{Materials and methods}

\section{Rice panel and field experimental procedures}

A diverse rice (Oryza sativa L.) panel consisting of 95 accessions, from indica (mainly) and japonica subspecies, composed especially by Brazilian elite cultivars (released by different breeding programs), cultivars from other countries, lines obtained through mutation breeding, and even one hybrid cultivar, was phenotyped regarding grain iron content and diverse morphological traits (Table 1).

The panel was grown, both for harvesting grains for iron content analysis and evaluating the morphological traits, in lowland conditions, at Capão do Leão - Rio Grande do Sul, Brazil, during the 2016/2017 crop season. The experimental design was randomized blocks, being each plot constituted by a one-meter row, spaced $0.20 \mathrm{~m}$. Forty-five viable seeds were sown per row. The flooded irrigation system was applied. All agronomic practices followed the technical Brazilian recommendation for rice (SOSBAI, 2016). Harvesting by hand was performed at the grain physiological maturity. 
Table 1. Genotypes assayed at Southern Brazil conditions for Fe content in brown and polished rice and agronomic traits, and their origin.

\begin{tabular}{|c|c|c|c|c|c|}
\hline Genotype & Origin & Genotype & Origin & Genotype & Origin \\
\hline BRS 358 & Brazil & EMPASC 100 & Brazil & $\mathrm{M} 1341^{1}$ & Brazi \\
\hline BRS 6 Chui & Brazil & EMPASC 101 & Brazil & M4431 & Brazi \\
\hline BRS 7 Taim & Brazil & EMPASC 102 & Brazil & M1410 1 & Brazi \\
\hline BRS AG & Brazil & EMPASC 103 & Brazil & Basmati 370 & Pakistan \\
\hline BRS Agrisul & Brazil & EMPASC 104 & Brazil & Bluebelli & USA \\
\hline BRS Atalanta & Brazil & EMPASC 105 & Brazil & Brilhante & Chile \\
\hline BRS Bojuru & Brazil & EPAGRI 106 & Brazil & Cacho Grande & Brazi \\
\hline BRS Firmeza & Brazil & EPAGRI 107 & Brazil & Carnaroli & Italy \\
\hline BRS Formoso & Brazil & EPAGRI 108 & Brazil & Carolina & USA \\
\hline BRS Fronteira & Brazil & EPAGRI 109 & Brazil & Japonês de Várzea & Unknown \\
\hline BRS Ligeirinho & Brazil & SC 173 & Brazil & Jasmine & Thailand \\
\hline BRS Pampa & Brazil & SC 460 & Brazil & Jasmine 85 & Thailand \\
\hline BRS Pampeira & Brazil & SCS 112 & Brazil & Koshihikari & Japan \\
\hline BRS Querência & Brazil & SCS 114 AndoSan & Brazil & Lemont & USA \\
\hline BRS Sinuelo CL & Brazil & SCS 116 Satoru & Brazil & Meio Chumbinho & Unknown \\
\hline BRSA $701 \mathrm{CL}$ & Brazil & SCS $117 \mathrm{CL}$ & Brazil & Nowrin Mochi & Unknown \\
\hline Cachinho & Brazil & SCS 118 Marques & Brazil & Puitá Inta CL & Argentina \\
\hline IAS 12-9 Formosa & Brazil & SCS 119 Rubi & Brazil & Rexoro & USA \\
\hline BRS Pelota & Brazil & SCS $121 \mathrm{CL}$ & Brazil & Sambuc & France \\
\hline Qualimax & Brazil & SCS $115 \mathrm{CL}$ & Brazil & Selenio & Italy \\
\hline BR IRGA 409 & Brazil & SCS BRS 111 & Brazil & Soulanet & France \\
\hline BR IRGA 410 & Brazil & IRAT 124 & France & Tetep & Vietnam \\
\hline BR IRGA 412 & Brazil & IRAT 162 & France & Tomoe Mochi & Japan \\
\hline BR IRGA 413 & Brazil & BRS CIRAD 302 & Brazil & & \\
\hline BR IRGA 414 & Brazil & SCS BRS Tio Taka & Brazil & & \\
\hline EEA 404 & Brazil & OR $63-252$ & Philippines & & \\
\hline EEA 405 & Brazil & MNA PB 0405 & Brazil & & \\
\hline IRGA 417 & Brazil & Zebu & Brazil & & \\
\hline IRGA 418 & Brazil & Guri Inta CL & Brazil & & \\
\hline IRGA 419 & Brazil & TOX 514-16-101-1 & Nigeria & & \\
\hline IRGA 420 & Brazil & Amarelo B & Unknown & & \\
\hline IRGA 424 CL & Brazil & Amaroo & Australia & & \\
\hline IRGA 427 & Brazil & Arbório & Italy & & \\
\hline IRGA 428 & Brazil & Austral & Unknown & & \\
\hline IRGA 429 & Brazil & $M 1150^{1}$ & Brazil & & \\
\hline BR IRGA 411 & Brazil & M13131 & Brazil & & \\
\hline
\end{tabular}

Mutant lines.

\section{Morphological traits evaluated}

Five plants per row were evaluated for the following twelve morphological rice descriptors and traits: flag leaf width (FLW) and length (FLL), main culm diameter (CD) and length (excluding the panicle) (CL), panicle length $(P L)$ and weight $(P W)$, number of panicles per plant (PP), number of infertile (IGP) and filled grains per panicle (FGP), weight of thousand grains (WTG), caryopsis length (CaL) and width (CaW). Correlation analyses between these traits and Fe content in brown (only husked) (FeB) and polished $(\mathrm{FeP})$ rice grains were performed.

\section{Iron quantification}

After drying, the samples of each genotype were divided in two parts, being one part only husked and the other husked and polished for two minutes in a mill tests (SUZUKI, model S21, MT). Next, all samples were milled (MARCONI, model MA020, Piracicaba/SP). In general, the preparation of samples for quantification followed Batista et al. (2014). Approximately $170 \mathrm{mg}$ of milled rice was weighted in a plastic tube (Falcon Corning, Tamaulipas, Mexico) and $1.2 \mathrm{~mL}$ of sub-distilled nitric acid (DST-1000, Savillex, EUA) (65\% Synth, Brazil) was added. The tubes remained for $48 \mathrm{~h}$ at $\sim 25^{\circ} \mathrm{C}$, with ocasional shaking. Finally, they were heated $\left(90^{\circ} \mathrm{C}\right)$ for $2 \mathrm{~h}$ using a water bath (CIENTEC, model 246, Piracicaba/SP, Brazil). After cooling, the volume of the sample was made up to 14 $\mathrm{mL}$ with ultrapure water (MILLIPORE, Milipak Filter Unit, São Paulo/SP, Brazil).

For the Fe quantification, the samples were injected in an inductively coupled plasma - mass spectrometer (ICP-MS Agilent 7900, Hachioji, Japan). Blank samples and reference materials were analyzed in every lot of digestion and quantification. All operational parameters of the equipment are described in Table 2. 
The calibration solutions were prepared by diluting the calibration standards of different elements $\left(10 \mathrm{mg} \mathrm{L}^{-1}\right.$ PerkinElmer, EUA) in $\mathrm{HNO}_{3} 5 \% \mathrm{v} / \mathrm{v}$. The calibration standards ranged from $10-1000 \mu \mathrm{g} \mathrm{L}^{-1}$.

\section{Statistical analyses}

All analyses were carried out with the aid of the software GENES (Cruz, 2013). The data were subjected to analysis of variance (ANOVA) by the $F$ test $(p \leq 0.05$ and $p \leq 0.01)$. Next, genetic parameters of genotypic and phenotypic variances, the coefficient of experimental variance and broad sense heritability were determined. Rice quantification in brown (FeB) and polished rice ( $\mathrm{FeP}$ ) were transformed through the equation $x=\log _{10}$, aiming to fulfil the ANOVA assumptions.
In the sequence, genotypic and phenotypic correlations were analyzed for the evaluated traits. The significance of the phenotypic correlation was calculated by a t-test (with n-2 degrees of freedom), and the genotypic correlations by a Mantel's test and a bootstrap analysis with 10,000 simulations. A weak degree of multicolinearity (according to the number of conditions 86.42) was found among the variables, thus no variable had to be excluded (Montgomery \& Peck, 1981). Even though, a constant $k=0.1002$ was adopted to minimize its effect. Next, the path analysis was carried out to indicate direct and indirect effects of the genotypic and phenotypic correlations on the morphological traits evaluated on Fe content in brown and polished rice.

Table 2 - Conditions and operational parameters for ICP-MS analysis.

\begin{tabular}{|c|c|}
\hline \multicolumn{2}{|l|}{ Monitored Isotopes } \\
\hline Helium Mode ( $L o D^{1}$ in $\left.\mu g L^{-1}\right)$ & $\begin{array}{l}{ }^{24} \mathrm{Mg}(0.005),{ }^{31} \mathrm{P}(32.9),{ }^{43} \mathrm{Ca}(1.5),{ }^{52} \mathrm{Cr}(0.006),{ }^{55} \mathrm{Mn}(0.04), \\
{ }^{57} \mathrm{Fe}(0.3),{ }^{59} \mathrm{Co}(0.0007),{ }^{63} \mathrm{Cu}(0.01),{ }^{66} \mathrm{Zn}(0.24),{ }^{75} \mathrm{As}(0.11) \text {, } \\
{ }^{8} \mathrm{Se}(0.25)\end{array}$ \\
\hline Internal standard (all modes) & ${ }^{193} \operatorname{Ir} 10 \mu g \mathrm{~L}^{-1}$ \\
\hline Peak pattern / Replicates / Sweeps & $3 / 2 / 100$ \\
\hline Radio Frequency Power & $1550 \mathrm{~W}$ \\
\hline Argon Flow Rate & $15 \mathrm{~L} \mathrm{~min}^{-1}$ \\
\hline Sample uptake / speed / stabilize & $8 \mathrm{~s} / 0.4 \mathrm{rps}^{2} / 4 \mathrm{~s}$ \\
\hline Nebulizer pump (acquisition) & 0.25 rps (all modes) \\
\hline Carrier Nebulizer Gas Flow rate & $1.07 \mathrm{~L} \mathrm{~min}^{-1}$ \\
\hline Nebulizer type & Mira Mist ${ }^{\mathrm{TM}}$ \\
\hline Spray chamber & UHMI Quartz Spray Chamber \\
\hline Temperature & $2^{\circ} \mathrm{C}$ \\
\hline Torch $(2.5 \mathrm{~mm})$ sample depth & $8 \mathrm{~mm}$ \\
\hline Interface & Nickel cones \\
\hline Sampler cone & $1.0 \mathrm{~mm}$ \\
\hline Skimmer & $0.9 \mathrm{~mm}$ \\
\hline Collision cell & Helium > $99.999 \%$ \\
\hline
\end{tabular}

1'LoD: Limit of detection; ${ }^{2}$ rps: rotation per second.

\section{Results}

The results of the analysis of variance are summarized in Table 3. All variables showed statistical significance for genotype factor, which evidences expressive genetic variability for this study. In general, the coefficients of heritability verified can be classified as from intermediate to high magnitude (Resende, 1995), ranging from $44.23 \%$ to $91.47 \%$. Fe content in brown and polished rice presented heritability of $44.95 \%$ and $44.23 \%$, respectively, which were the smallest coefficients observed in this work.

Analysis of phenotypic and genotypic linear correlation between traits were carried out, and the results are presented in Table 4. Although many significant correlations were observed, especial attention is given here to associations between all morphological traits and $\mathrm{Fe}$ content in rice. Between $\mathrm{Fe}$ in brown and polished grains, there was only found correlation of phenotypic nature, which was of positive direction, but of small magnitude (0.293).

For brown rice, both phenotypic and genotypic significant correlations were found with flag leaf width, panicles per plant, caryopsis length (positive), culm length and caryopsis width (negative). For polished rice, panicle length, panicles per plant, infertile grains per panicle (positive), panicle weight and caryopsis width (negative) were the traits which showed phenotypic and genotypic significant correlations. Thus, considering simultaneously the phenotypic and genotypic linear correlation, panicles per plant (positive) and caryopsis width (negative) were the morphological traits showing significant linear correlation with Fe content in both brown and polished rice. 
Table 3. Summary of analysis of variance and estimative of genetic and phenotypic parameters of morphological traits and related to Fe content assayed in 95 rice genotypes grown at Southern Brazil.

\begin{tabular}{|c|c|c|c|c|c|c|c|c|}
\hline \multirow{2}{*}{$\mathrm{SV}^{1}$} & \multirow{2}{*}{ DF } & \multicolumn{7}{|c|}{ Main Squares } \\
\hline & & FLL & FLW & CD & $\mathrm{CL}$ & $\mathrm{PL}$ & PP & PW \\
\hline $\mathrm{G}$ & 94 & $42.79^{\star *}$ & $0.06^{\star \star}$ & $0.005^{\star *}$ & $241.98^{\star \star}$ & $15.45^{\star *}$ & $12.44^{* \star}$ & $1.07^{* \star}$ \\
\hline B & 2 & 18.06 & 0.02 & 0.0007 & 35.20 & 1.65 & 5.02 & 0.10 \\
\hline$r$ & 188 & 11.52 & 0.01 & 0.002 & 78.99 & 4.65 & 6.73 & 0.35 \\
\hline$\mu$ & - & 25.24 & 1.32 & 0.35 & 72.70 & 22.05 & 8.70 & 2.74 \\
\hline CV (\%) & - & 13.44 & 10.16 & 14.07 & 12.22 & 9.77 & 29.81 & 21.59 \\
\hline$\sigma^{2} g^{2}$ & - & 10.42 & 0.02 & 0.001 & 54.33 & 3.60 & 4.14 & 0.24 \\
\hline$\sigma^{2} p^{2}$ & - & 14.26 & 0.01 & 0.001 & 80.66 & 5.15 & 1.90 & 0.35 \\
\hline \multirow{2}{*}{$\mathrm{H}^{2}(\%)$} & - & 73.06 & 72.01 & 55.51 & 67.35 & 69.90 & 45.82 & 67.24 \\
\hline & & FGP & IGP & WTG & $\mathrm{CaL}$ & CaW & $\mathrm{FeB}$ & $\mathrm{FeP}$ \\
\hline $\mathrm{G}$ & 94 & $2114.4^{* \star}$ & $480.95^{\star \star}$ & $11.72^{\star \star}$ & $2.25^{\star \star}$ & $0.52^{\star \star}$ & $0.01^{* \star}$ & $0.04^{* *}$ \\
\hline B & 2 & 463.30 & 380.97 & 3.67 & 0.03 & 0.24 & 0.16 & 0.62 \\
\hline$r$ & 188 & 570.37 & 140.27 & 5.13 & 0.39 & 0.14 & 0.10 & 0.25 \\
\hline$\mu$ & - & 95.55 & 25.06 & 26.07 & 9.22 & 2.74 & 4.10 & 3.58 \\
\hline CV (\%) & - & 24.99 & 47.24 & 8.69 & 6.83 & 13.74 & 2.48 & 4.46 \\
\hline$\sigma^{2} g^{2}$ & - & 514.69 & 113.55 & 18.36 & 0.61 & 0.17 & 0.002 & 0.006 \\
\hline$\sigma^{2} p^{2}$ & - & 704.82 & 160.31 & 20.07 & 0.75 & 0.12 & 0.006 & 0.01 \\
\hline $\mathrm{H}^{2}(\%)$ & - & 73.025 & 70.83 & 91.47 & 82.37 & 72.65 & 44.95 & 44.23 \\
\hline
\end{tabular}

iSV - source of variation; DF - degrees of freedom; G - genotype; B - block; $r$ - residue; $\mu$-average; CV - coefficient of variation (\%); $\sigma^{2}{ }^{2}$ - genetic variation; $\sigma^{2} p^{2}$ - phenotypic variation; $\mathrm{H}^{2}$ - broad sense heritability (\%); FLL - flag leaf length; FLW - flag leaf width; CD - culm diameter; CL - culm length; PL - panicle length; PP - number of panicles per plant; PW - panicle weight; FGP - number of filled grains per panilcle; IGP - number of infertile grains per panicle; WTG - weight of thousand grains; $\mathrm{CaL}$ - caryopsis length; $\mathrm{CaW}$ - caryopsis width; $\mathrm{FeB}$ - Fe content in brown rice; FeP - Fe content in polished rice grains. ${ }^{* *}$ significant at $p \leq 0.01$ by the $F$ test.

Table 4. Phenotypic and genotypic coefficients of correlation for 14 traits assayed in 95 rice genotypes grown at Southern Brazil.

\begin{tabular}{|c|c|c|c|c|c|c|c|c|c|c|c|c|c|c|c|}
\hline & \multirow{2}{*}{ Trait } & \multicolumn{14}{|c|}{$\mathbf{R f}^{1}$} \\
\hline & & FLL & FLW & $C D$ & $\mathrm{CL}$ & $\mathrm{PL}$ & PP & $\overline{\mathrm{PW}}$ & FGP & IGP & WTG & $\mathrm{CaL}$ & CaW & FeB & $\mathrm{FeP}$ \\
\hline \multirow{14}{*}{ קי } & $\overline{\mathrm{FLL}}$ & & 0.1 & 0.1 & 0.1 & $0.3^{\star *}$ & 0.0 & -0.1 & -0.2 & $0.4^{* \star}$ & 0.1 & -0.1 & 0.0 & 0.0 & 0.2 \\
\hline & FLW & 0.0 & & $0.3^{* *}$ & -0.1 & $0.5^{* *}$ & 0.1 & $0.3^{* *}$ & $0.3^{* *}$ & $0.4^{\star \star}$ & -0.2 & $0.3^{* *}$ & $-0.3^{* *}$ & $0.3^{* *}$ & 0.2 \\
\hline & CD & 0.1 & 0.3 & & $0.4^{* *}$ & 0.1 & -0.2 & $0.4^{* *}$ & 0.1 & $0.3^{* *}$ & $0.3^{* *}$ & 0.1 & 0.2 & 0.1 & -0.1 \\
\hline & CL & 0.1 & -0.1 & $0.5^{+}$ & & 0.1 & $-0.4^{* *}$ & $0.2^{*}$ & 0.0 & 0.1 & $0.3^{\star *}$ & -0.2 & $0.5^{\star *}$ & $-0.3^{* *}$ & $-0.3^{* *}$ \\
\hline & PL & 0.3 & $0.5^{+}$ & 0.2 & 0.1 & & 0.1 & $0.4^{* *}$ & $0.4^{* *}$ & $0.4^{\star *}$ & -0.2 & $0.4^{* \star}$ & $-0.3^{* *}$ & 0.2 & $0.3^{\star *}$ \\
\hline & PP & -0.1 & 0.3 & -0.3 & $-0.6^{++}$ & 0.2 & & $-0.2^{*}$ & 0.0 & -0.1 & $-0.4^{\star *}$ & 0.2 & $-0.5^{\star \star}$ & $0.3^{* *}$ & $0.3^{*}$ \\
\hline & PW & -0.1 & 0.3 & $0.5^{+}$ & 0.2 & $0.4^{+}$ & -0.4 & & $0.7^{* *}$ & 0.0 & 0.2 & 0.1 & 0.2 & -0.1 & $-0.3^{* *}$ \\
\hline & FGP & -0.3 & $0.4^{+}$ & 0.0 & -0.0 & $0.4^{+}$ & 0.1 & $0.6^{++}$ & & -0.0 & $-0.4^{* \star}$ & -0.2 & -0.2 & 0.1 & -0.2 \\
\hline & IGP & $0.4^{+}$ & $0.4^{+}$ & $0.4^{+}$ & 0.1 & $0.5^{++}$ & -0.1 & 0.1 & 0.0 & & -0.1 & 0.2 & $-0.2^{*}$ & 0.1 & $0.2^{*}$ \\
\hline & WTG & 0.1 & -0.2 & $0.3^{+}$ & $0.4^{+}$ & -0.2 & $-0.6^{++}$ & 0.3 & $-0.5^{++}$ & -0.1 & & $0.2^{*}$ & $0.6^{* *}$ & $-0.2^{*}$ & $-0.2^{*}$ \\
\hline & $\mathrm{CaL}$ & -0.1 & 0.3 & 0.2 & -0.1 & $0.5^{++}$ & $0.4^{+}$ & 0.2 & -0.2 & 0.2 & 0.2 & & $-0.4^{\star \star}$ & $0.3^{* *}$ & $0.3^{*}$ \\
\hline & CaW & 0.1 & $-0.4^{+}$ & 0.2 & $0.5^{++}$ & $-0.4^{+}$ & $-0.8^{++}$ & 0.2 & -0.3 & -0.3 & $0.7^{++}$ & $-0.5^{++}$ & & $-0.4^{* *}$ & $-0.4^{* *}$ \\
\hline & $\mathrm{FeB}$ & -0.1 & $0.6^{+}$ & 0.2 & $-0.5^{+}$ & 0.3 & $0.8^{++}$ & -0.1 & 0.1 & 0.2 & -0.3 & $0.6^{++}$ & $-0.6^{++}$ & & $0.3^{*}$ \\
\hline & $\mathrm{FeP}$ & 0.4 & 0.3 & -0.1 & -0.3 & $0.5^{+}$ & $0.6^{+}$ & $-0.5^{+}$ & -0.2 & $0.4^{+}$ & -0.3 & 0.4 & $-0.6^{++}$ & 0.5 & \\
\hline
\end{tabular}




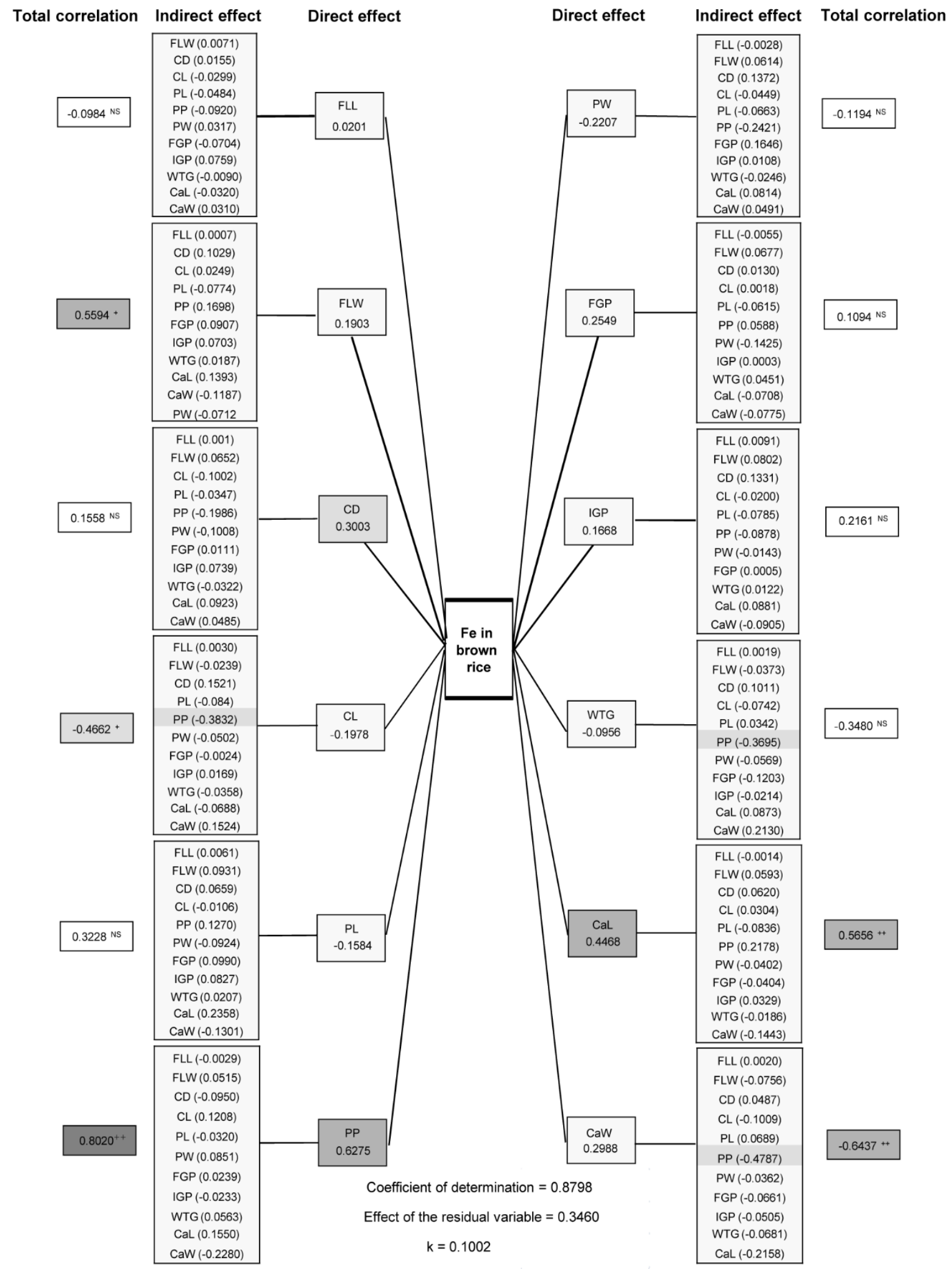

Figure 1 - Estimative of the direct and indirect effects of the path analysis coeficients of correlation from the phenotypic and genotypic correlations on the trait $\mathrm{Fe}$ in brown rice grains. FLL - flag leaf length (cm); FLW - flag leaf width $(\mathrm{cm})$; $C D$ - culm diameter $(\mathrm{cm}) ; \mathrm{CL}$ - culm length $(\mathrm{cm}) ; \mathrm{PL}$ - panicle length $(\mathrm{cm}) ; \mathrm{PP}$ - number of panicles per plant; PW - panicle weight (g); FGP - number of filled grains per panilcle; IGP - number of infertile grains per panicle; WTG - weight of thousand grains (g); CaL - caryopsis length (cm); CaW - caryopsis width $(\mathrm{cm}) .{ }^{+},{ }^{++}$: significant at $p \leq 0.05$ and $p \leq 0.01$, according to Mantel's test. NS: Not significant. For a better visualization coloring of the coefficients followed the classification of Pearson's coefficients of correlation revised by Mukaka (2012). 


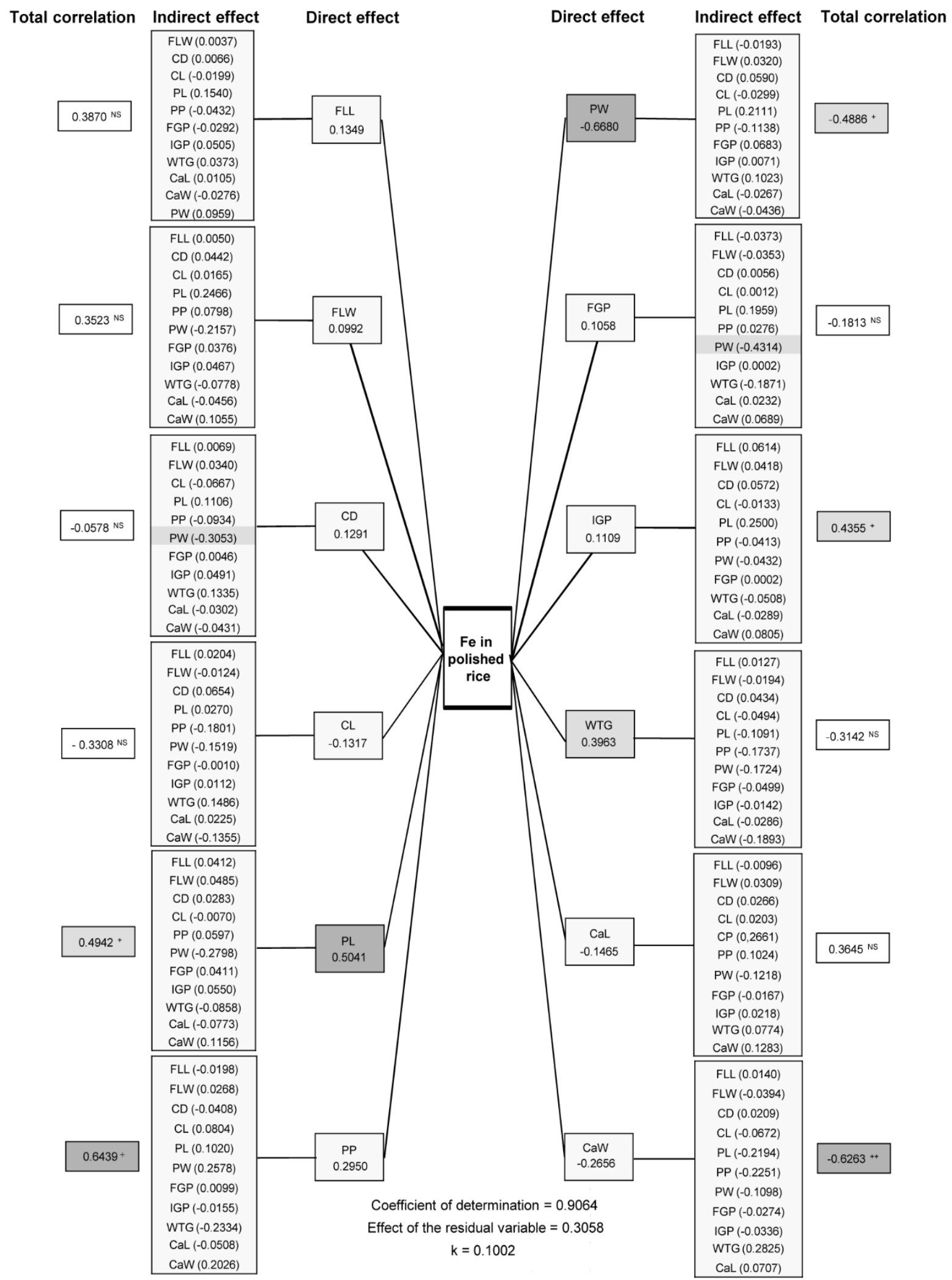

Figure 2 - Estimative of the direct and indirect effects of the path analysis coeficients of correlation from the phenotypic and genotypic correlations on the trait Fe in polished rice grains. FLL - flag leaf length (cm); FLW - flag leaf width (cm); CD - culm diameter $(\mathrm{cm}) ; C L$ - culm length $(\mathrm{cm}) ; \mathrm{PL}$ - panicle length $(\mathrm{cm}) ; \mathrm{PP}$ - number of panicles per plant; PW - panicle weight (g); FGP - number of filled grains per panicle; IGP - number of infertile grains per panicle; WTG - weight of thousand grains $(\mathrm{g})$; CaL - caryopsis length $(\mathrm{cm})$; CaW - caryopsis width $(\mathrm{cm}) .{ }^{+},{ }^{++}$: significant at $p \leq 0.05$ and $p \leq 0.01$, according to Mantel's test. NS: Not significant. For a better visualization coloring of the coefficients followed the classification of Pearson's coefficients of correlation revised by Mukaka (2012). 
In order to better understand the real association between traits under analysis, finding secondary traits, i.e., of indirect effect which have also to be taken into account in the indirect selection approach, Path analysis (Wright, 1923) was applied. As the coefficient of determination of the model for the phenotypic effect showed low magnitude, only the genotypic correlation was considered in this study (Figures 1 and 2). In general, the genotypic correlations between traits showed both negative and positive effects with different magnitudes, allowing to identify critical secondary traits. The estimative of the direct and indirect effect of the analyzed traits on the main variable $\mathrm{Fe}$ in brown rice evidenced panicles per plant as the most influent trait, with a high direct effect (0.6275), illustrating a true association between these traits, being caryopsis width the variable with the most expressive secondary effect on the path $(-0.2280)$. Secondly, caryopsis width, which has shown a negative linear (total) correlation of strong magnitude on $\mathrm{Fe}$ in brown rice, presented a considerable direct positive effect (0.2988) and panicles per plant $(-0.4787)$ and caryopsis length (0.2158 ) presented the most significant indirect impact. Other traits, such as culm and caryopsis length and flag leaf width also deserve consideration, as well as the traits which influenced them indirectly.

The results of the path analysis for $\mathrm{Fe}$ in polished rice as a function of explanatory traits also evidenced both positive and negative associations between the variables. Panicles per plant expressively contributed in a direct form (0.2950) and was influenced indirectly via panicle weight $(0.2578)$ and caryopsis width (0.2026). Caryopsis width showed a direct negative effect $(-0.2656)$ similar to the indirect effects via panicles per plant $(-0.2251)$ and panicle length $(-0.2194)$. Another expressive trait, panicle weight, which has shown significant negative correlation with $\mathrm{Fe}$ in polished rice, presented the highest direct effect of this study $(-0.6680)$ on the main variable, which highlight the relationship between these traits. On the other hand, number of infertile grains per panicle showed the smallest direct effect on the main variable, thus all the other traits contribuited to the total correlation observed.

\section{Discussion}

The present study aimed to investigate the association between a set of morphological traits, mostly of agronomic importance, and Fe content in rice grains, with the final objective of finding among the former the most promising ones for use in indirect selection strategies in breeding programs aiming iron biofortification of rice. Indirect selection is an approach in which the selection is performed on one or more secondary traits with the final aim to improve another main trait, based on the correlation between them. Before carrying out this approach, many aspects about the traits have to be firstly considered, being the heritability one of them.
Heritability can be defined as the degree of correspondence between the phenotype and the breeding value of an individual for a given trait (Hallauer et al., 1988). It is influenced, at least in part, by the amount of loci controlling a given trait, and once known, helps the selection of this and other associated traits (Amorim et al., 2008; Silva et al., 2011). Its coefficient is considered low when between 0.01 and 0.15 , intermediate when between 0.15 and 0.50 and high when the values are higher than 0.50 (Resende, 1995). The coeficients of heritability of $\mathrm{Fe}$ in brown and polished rice were only of intermediate magnitude, however, most of the other studied traits showed a high heritability, illustrating the potential application of the indirect selection aiming improvement in Fe grain content in the studied genotypes.

Despite the valuable information obtained through the analysis of linear correlation, it has to be considered that it is only a method of simple linear association (Vencovsky \& Barriga, 1992), thus due the importance of the cause and effect relationships, the path analysis (Wright, 1923) was carried out separately for each $\mathrm{Fe}$ content trait, i.e., $\mathrm{Fe}$ in brown and in polished rice. This analysis allows identifying which traits have a more pronounced direct or indirect effect on a primary (main) trait. Moreover, allows a more profound analysis regarding the influence of the traits present in the study, that can help to explain the existence of positive and negative correlations, with different magnitudes among the studied variables (Silva et al., 2005).

Among the possible causes of the correlation between traits is pleiotropy, a phenomenon in which one gene defines the expression of two or more traits, and linkage disequilibrium among pairs of genes, which can be maintained along many generations (Carmona et al., 2015). In case of grain quality traits of rice, they exhibit complex relationships mainly due to the mentioned genetic forces, making most of the time, the breeding process an arduous task. It is clearly illustrated in this study, when the genotypic correlation between $\mathrm{Fe}$ in brown and polished rice was not significant, justifying the analysis and further employment of other traits in more elaborated breeding schemes.

In addition to a strong association and high heritability, a trait has a promising use in indirect selection if it is cheaper, easier and time-saving to evaluate in comparison to the main trait or even if the trait is important per se, i.e., agronomically relevant, so breeding would lead to improvements in more than one trait simultaneously (Carvalho et al., 2004). Taking all these criteria into account, the most promising traits to be used in indirect selection aiming Fe biofortification in rice are panicles per plant and caryopsis width, i.e., when using the studied germplasm as base.

Panicles per plant presented the highest coefficient of linear correlation with both brown and polished rice, in the positive direction, and also showed one of the highest direct effects in the path analysis, being thus, less affected by other traits, showing a true 
association with the main traits (Vencovsky \& Barriga, 1992). In terms of convenience, it is a yield component, therefore using it for selection would possibly benefit the productive potential of the genotype, and it is considerably cheap to evaluate, as well as simple and fast. The only drawback of using panicles per plant when breeding using this germplasm as the base, is the heritability verified, which was only of intermediate magnitude, as it is a polygenic trait and thus influenced by the environment (Rebolledo et al., 2016).

Caryopsis width has also been shown as a convenient trait for indirect selection. The coefficient of correlation observed was negative, indicating that the narrower the grain, the higher the $\mathrm{Fe}$ content in rice. Considering that in Brazil the more consumed kind of grain is the long and thin type, the so-called "agulhinha" (CONAB, 2015; Streck et al., 2017), breeding programs can maintain their ideotype of plant, thus, not being necessary to change and selecting for other grain types when targeting higher Fe content. Oppositing to panicles per plant, caryopsis width presented high coefficient of heritability, however, smaller direct effect in the path analysis, thus making the indirect selection more complicated, as other traits have to be considered simultaneously.

After uptaken by roots, $\mathrm{Fe}$ is transported to leaves and other storage organs (Gao et al., 2016; Kim \& Guerinot, 2007). The association among the flag leaf and Fe content in rice grains was here found and has been already documented, e.g., it was already verified the remobilization of $\mathrm{Fe}$ from the flag leaf to rice grains (Sperotto et al., 2010). On the other hand, however, another study verified that removing the flag leaf did not have effect on the $\mathrm{Fe}$ content in rice grains (Sperotto et al., 2013). Thus, further research is required before moving efforts to improve flag leaf size with the final objective of $\mathrm{Fe}$ biofortification in this cereal.

The lenght of the caryopsis was also associated, in this case positively, with higher Fe content, especially in brown rice. This correlation was previously verified by Sellappan et al. (2009) and studies carried out by Zhang et al. (2004) on a rice genotype with black pericarp have also found positive correlations between caryopsis lenght and $\mathrm{Fe}$ content in grain. Other traits, which deserve attention in this study and in breeding programs, are culm length and panicle length. The results found here suggest that breeding for smaller plants, which has been already a target worldwide for decades, as well as for longer panicles, which can contribuite to yield potential, can also contribuite to the increase of $\mathrm{Fe}$ content in rice grains. All these results encourage breeding $\mathrm{Fe}$ biofortified rice, as this improvement would not impair most of other important breeding targets.

In this regard, some exceptions found here were for number of infertile grains per panicle and panicle weight, which associated with higher $\mathrm{Fe}$ content but at the same time usually in an opposite way to yield, thus, must not be considered in indirect selection. Given the importance of the approach but also the possible drawbacks applying indirect selection, similar work has been already carried out on rice in other countries (Anandan et al., 2011; Ajmera et al., 2017; Kalyan et al., 2017; Rathod et al., 2017; Sowmiya \& Venkatesan, 2017). Differences in the results reported in these studies were found, which can be mainly attributed to the different germplasms assayed, but also environmental conditions.

Other breeding approaches have been applied aiming $\mathrm{Fe}$ biofortification in rice. Efforts have been carried out, for example, in the development of transgenic plants, and different genes were assayed. Even though the strategies using genetic transformation resulted in the increase of $\mathrm{Fe}$ content, milling is still responsible for many losses (revised by Santos et al., 2017). Thus, the conventional selection of genotypes with high Fe content followed by hybridization continue to be an interesting alternative. It is important to emphasize that mineral content in rice grain are quantitative traits, strongly affected by the environment, thus the indirect selection can assist this process. Although important research has been carried out worldwide, to the best of our knowledge, this is one of the largest studies of this kind using Brazilian elite rice germplasm, which emphasizes the importance of this work.

\section{Conclusion}

Panicles per plant and caryopsis width are the most promising traits for use in indirect selection aiming Fe biofortification in brown and polished rice, however, in the case of the latter, traits of secondary effect have to be considered. Other traits, such as caryopsis length also deserve attention in breeding programs with this objective.

\section{Acknowledgments}

This study was supported by Conselho Nacional de Desenvolvimento Científico e Tecnológico (CNPq) - Brazil, under grant no. 401902/2016-1. CNPq, Coordenação de Aperfeiçoamento de Pessoal de Nível Superior (CAPES) and Fundação de Amparo à Pesquisa do Estado do Rio Grande do Sul (FAPERGS) also provided fellowships for the investigators and students. This work is part of the dissertation (Master degree in Sciences) of the first author.

\section{References}

Ajmera S, Kumar SS, Ravindrababu V (2017) Path coefficient analysis for grain iron and zinc contents and others traits in rice genotypes. Bulletin of Environment, Pharmacology and Life Sciences 6:160-163.

Amorim EP, Ramos NP, Ungaro MRG, Kiihl TAM (2008) Correlações e análise de trilha em girassol. Bragantia 67:307-316. 
Anandan A, Rajiv G, Eswaran R, Prakash M (2011) Genotypic variation and relationships between quality traits and trace elements in traditional and improved rice (Oryza sativa L.) genotypes. Journal of Food Science 76:122-130.

Barbosa RP, Neto FA, Gravina LM, Gravina GA, Portela MG, Bezerra AA (2017) Early selection of sugarcane using path analysis. Genetics and molecular research: GMR 16:1-8.

Batista BL, Nigar M, Mestrot A, Alves Rocha B, Barbosa Junior $F$, Price $A H$, Raab A, Feldmann $J$ (2014) Identification and quantification of phytochelatins in roots of rice to long-term exposure: evidence of individual role on arsenic accumulation and translocation. Journal of Experimental Botany 65:1467-1479.

Bouis HE, Welch RM (2010) Biofortification-a sustainable agricultural strategy for reducing micronutrient malnutrition in the global south. Crop Science 50:S-20.

Camaschella C (2015) Iron-deficiency anemia. New England Journal of Medicine 372:1832-1843.

Carmona PA, Peixoto JR, Amaro GB, Mendonça MA (2015) Genetic divergence of sweet potato accessions based on morpho-agronomic descriptors of the roots. Horticultura Brasileira 33:241-250.

Carvalho FIF, Lorencetti C, Benin G (2004) Estimativas e implicações da correlação no melhoramento vegetal. Editora e Gráfica da UFPel. Pelotas. 142p.

Companhia Nacional de Abastecimento (2015) A cultura do arroz. Brasília: Conab. 180p.

Cruz CD (2013) GENES - a software package for analysis in experimental statistics and quantitative genetics. Acta Scientiarum. Agronomy 35:271-276.

Falconer DS (1981) Introdução à genética quantitativa. Viçosa: UFV. 279p.

Falconer DS, Mackay TFC (1996) Introduction to quantitative genetics, Ed. 4. Longmans Green, Harlow, Essex, UK. 480p.

Gao L, Chang J, Chen R, Li H, Lu H, Tao L, Xiong J (2016) Comparison on cellular mechanisms of iron and cadmium accumulation in rice: prospects for cultivating Fe-rich but Cd-free rice. Rice 9:39.

Hackl L, Speich C, Zeder C, Sánchez-Ferrer A, Adelmann $\mathrm{H}$, De Pee S, Tay F, Zimmermann MB, Moretti D (2017) Cold extrusion but not coating affects iron bioavailability from fortified rice in young women and Is associated with modifications in starch microstructure and mineral retention during cooking. The Journal of Nutrition 147:2319-2325.
Hallauer AR, Carena MJ, Miranda Filho JD (1988) Quantitative genetics in maize breeding, 2nd ed., Springer Science \& Business Media. 663p.

Huang Y, Sun C, Min J, Chen Y, Tong C, Bao J (2015) Association mapping of quantitative trait loci for mineral element contents in whole grain rice (Oryza sativa L.). Journal of Agricultural and Food Chemistry 63:10885-10892 .

Kalyan B, Krishna KR, Rao LV (2017) Path coefficient analysis for yield and yield contributing traits in rice (Oryza sativa L.) genotypes. International Journal of Current Microbiology and Applied Sciences 6:2680$-2687$.

Khush GS, Lee S, Cho JI, Jeon JS (2012) Biofortification of crops for reducing malnutrition. Plant Biotechnology Reports, 6(3):195-202.

Kim SA, Guerinot ML (2007) Mining iron: Iron uptake and transport in plants. FEBS Letters 581:2273-2280.

Mohan V, Ruchi V, Gayathri R, Ramya BM, Shobana S, Anjana RM, Unnikrishnan R, Sudha V (2017) Hurdles in brown rice consumption. In: Manickavasagan A, Santhakumar C, Venkatachalapathy N (ed) Brown Rice, p. 255-269.

Montgomery DC, Peck EA. Introduction to linear regression analysis. New York : J. Wiley, 1981. 504p.

Mukaka MM (2012) A guide to appropriate use of correlation coefficient in medical research. Malawi Medical Journal 24:69-71.

Murgia I, Arosio P, Tarantino D, Soave C (2012) Biofortification for combating 'hidden hunger' for iron. Trends in plant science, 17(1):47-55.

Nogueira APO, Sediyama T, Sousa LB, Hamawak OT, Cruz CD, Pereira DG, Matsuo E (2012) Análise de trilha e correlações entre caracteres em soja cultivada em duas épocas de semeadura. Bioscience Journal 28:877-888.

Rathod R, Rao DS, Babu VR, Bharathi M (2017) Correlation and path coefficient analysis for yield, yield attributing and nutritional traits in rice (Oryza sativa L.). International Journal of Current Microbiology and Applied Sciences 6:183-188.

Rebolledo MC, Peña AL, Duitama J, Cruz DF, Dingkuhn M, Grenier C, Tohme J (2016) Combining image analysis, genome wide association studies and different field trials to reveal stable genetic regions related to panicle architecture and the number of spikelets per panicle in rice. Frontiers in Plant Science 7:1354. 
Resende MDV (1995) Delineamento de experimentos de seleção para maximização da acurácia seletiva e do progresso genético. Revista Árvore 19:479-500.

Saltzman A, Birol E, Bouis HE, Boy E, De Moura FF, Islam Y, Pfeiffer WH (2013) Biofortification: progress toward a more nourishing future. Global Food Security 2(1):9-17.

Santos RS dos, Araujo Júnior ATD, Pegoraro C, Oliveira AC (2017) Dealing with iron metabolism in rice: from breeding for stress tolerance to biofortification. Genetics and Molecular Biology 40:312-325.

Sellappan K, Datta K, Parkhi V, Datta SK (2009) Rice caryopsis structure in relation to distribution of micronutrients (iron, zinc, $\beta$-carotene) of rice cultivars including transgenic indica rice. Plant Science 177:557-562.

Sharma P, Aggarwal P, Kaur A (2017) Biofortification: $A$ new approach to eradicate hidden hunger. Food Reviews International 33:1-21.

Silva JAG, Schwertner DV, Kruger CAMB, Carbonera R, Maixner AR, Garcia DC, Crestani M, Gaviraghi F, Martins JAK, Matter E (2011) Estimativas de herdabilidade e correlações para caracteres agronômicos em girassol. Revista Brasileira de Agrociência 17:51-59.

Silva SA, Carvalho FIF, Nedel JL, Cruz PJ, Silva JAG, Caetano VR, Hartwig I, Sousa CS (2005) Análise de trilha para os componentes de rendimento de grãos em trigo. Bragantia 64:191-196.

Sociedade Sul Brasileira de Arroz Irrigado (2016) Arroz irrigado: recomendações técnicas da pesquisa para o Sul do Brazil. Pelotas, SOSBAI. 197p.

Sowmiya CA, Venkatesan M (2017) Studies on Correlation and Path Coefficient Analysis in Rice (Oryza Sativa L.). International Journal of Current Microbiology and Appied Sciences 6:1757-1763.
Sperotto RA, Boff T, Duarte GL, Santos LS, Grusak M, Fett JP (2010) Identification of putative target genes to manipulate $\mathrm{Fe}$ and $\mathrm{Zn}$ concentrations in rice grains. Journal of Plant Physiology 167:1500-1506.

Sperotto RA, Ricachenevsky FK, Waldow VA, Fett JP (2012) Iron biofortification in rice: it's a long way to the top. Plant Science 190:24-39.

Sperotto RA, Ricachenevsky FK, Waldow VDA, Müller ALH, Dressler VL, Fett JP (2013) Rice grain Fe, Mn and $\mathrm{Zn}$ accumulation: How important are flag leaves and seed number. Plant, Soil and Environment 59:262266.

Stein AJ (2010) Global impacts of human mineral malnutrition. Plant and soil 335(1-2):133-154.

Streck EA, Aguiar GA, Magalhães Júnior AM, Facchinello PH, Oliveira AC (2017) Variabilidade fenotípica de genótipos de arroz irrigado via análise multivariada. Revista Ciência Agronômica 48:101-109.

Vasconcelos MW, Gruissem W, Bhullar NK (2017) Iron biofortification in the 21st century: setting realistic targets, overcoming obstacles, and new strategies for healthy nutrition. Current Opinion in Biotechnology 44:8-15.

Vencovsky R, Barriga P (1992) Genética biométrica no fitomelhoramento. Ribeirão Preto: Sociedade Brasileira de Genética, 196p.

Wright S (1921) Correlation and causation. Journal of Agricultural Research 20:557-585.

Wright S (1923) Theory of path coefficients. Genetics 8:239-285.

Zhang MW, Guo BJ, Peng ZM (2004) Genetic effects on $\mathrm{Fe}, \mathrm{Zn}, \mathrm{Mn}$ and $\mathrm{P}$ contents in Indica black pericarp rice and their genetic correlations with grain characteristics. Euphytica 135:315-323. 